\title{
Protein isoforms. Origin, structure and functions
}

\author{
O. V. Novosylna \\ Institute of Molecular Biology and Genetics, NAS of Ukraine \\ 150, Akademika Zabolotnoho Str., Kyiv, Ukraine, 03680 \\ aleksnova@yahoo.com
}

\begin{abstract}
Many proteins in mammalian organism exist as isoforms. These isoforms can be encoded by different genes or produced by alternative splicing of one gene. Despite rapid instrumental progress in the isoform identification, the reasons for their existence and specific functions remain largely unknown. During recent years, attention of researchers was mostly concentrated on spliced isoforms, while the variants of the same protein coded by different genes can play an essential role in different cell processes. This review presents examples of different potential functions of the protein isoforms coded by different genes. Molecular background which could provide a difference between highly homologous protein variants is discussed with an example of isoforms translation elongation factor 1A (eEF1A).
\end{abstract}

Keyword s: protein isoforms, eukaryotic translation, eEF1A

\section{Origin of the protein isoforms}

The protein isoforms are closely related gene products which can perform both similar and quite different biological functions. The isoforms may differ by biological activity, regulatory potential, intercellular distribution, different spatio-temporal expression etc. The protein isoforms are either products of the same gene or the family of genes originated from a single predecessor.

In the first case, a single gene produces several mRNAs by separation and subsequent re-joining of the pre-mRNA exons. Generation of alternative exons is achieved by i) tandem duplication with subsequent divergence of exons; ii) translocation of exons into novel gene context; iii) mutations in the intron or flanking sequence with creation of $\mathrm{N}$-terminal, C-terminal or internal exons [1]. The alternate splicing of equivalent homological exons may have evolutionary importance, as the exchange of homological exons may lead to fine tuning of functions of the corresponding protein. On the contrary, a bulk of the alternative splicing isoforms is predicted to arise due to the large insertions or deletions, or non-homologous substitutions. However, the precise proteomic experiments revealed only a small fraction of predicted alternative isoforms. It appears that

(C) 2017 O. V. Novosylna; Published by the Institute of Molecular Biology and Genetics, NAS of Ukraine on behalf of Biopolymers and Cell. This is an Open Access article distributed under the terms of the Creative Commons Attribution License (http://creativecommons.org/licenses/by/4.0/), which permits unrestricted reuse, distribution, and reproduction in any medium, provided the original work is properly cited 
the vast majority of annotated alternative transcripts may not ever be translated into proteins [2].

In the second case, the multiple copies of the same gene are generated by at least three mechanisms: unequal crossing over during meiosis; tandem duplications resulting from DNA replication errors, or translocation of a gene copy to another chromosome [1].

Evolutionary development of multicellular organisms gave a ground to the appearance of the protein isoforms with specialized functions. There are a number of examples of the different proteins isoforms fulfilling similar, diverse and sometimes antagonistic functions. We focus the review on the functional diversity of the protein isoforms coded by different genes.

\section{Dissimilar functions of the same protein isoforms}

A family of scaffold proteins IQGAP (IQ Motif Containing GTPase Activating Protein) comprise three evolutionary conserved isoforms [3]. All three isoforms participate in controlling the dynamics of cytoskeleton, intracellular signaling and provide a large amount of protein-protein interactions. However, IQGAP1 is expressed in all tissues, IQGAP2 is present mostly in liver whereas the expression of IQGAP3 is limited to brain, which indicates a likelihood of unique functions of every isoform [4]. All three isoforms interact with actin [5-7] and calmodulin [5, 8, 9]. However, for every isoform the specific protein partners were revealed: IQGAP3 binds only ERK1 [10], while IQGAP1 interact with both ERK1 [11] and ERK2 [12]. The interaction of IQGAP3 with annilin was shown, whereas both IQGAP1 and IQGAP2 could not interact with this protein [13]. In living cells, the inhibition of the mRNA coding for IQGAP2 or IQGAP3, contrary to IQGAP1, negatively influenced both the growth and length of axons [4]. Interestingly, a number of known protein partners of IQGAP1 is much greater than for IQGAP2 and IQGAP3 [3]. The functional meaning of such difference awaits a special investigation.

A family of plakophilins comprises three homologous isoforms. Until recently, plakophilins were considered to be mostly the structural proteins, the desmosomal components, which increase cell adhesion due to binding to intermediate filaments of the cytoskeleton [14] Now it is known that plakophilins possess also a scaffold function, controlling a variety of cellular processes and participating in the development of carcinogenesis, cardiomyopathy, hereditary diseases etc. $[15,16]$ This family is a good example of the unique and sometimes functionally antagonistic character of the protein isoforms. In particular, the isoforms differ by cellular localization and kinetics of desmosome formation de novo and are controlled by different mechanisms [17, 18]. Importantly, plakophilin 3 prevents the formation of hyperadhesive desmosomes in a protein kinase $\mathrm{C}$ alpha-dependent manner, even in the presence of plakophilin 1 which normally stimulates their formation contributing to the stable intercellular co-adhesion [19].

Different participation of very similar isoforms in cell signaling is demonstrated by three closely related human genes $\operatorname{Kras}$ (4A, 4B), Hras and Nras, the products of which are the main members of Ras subfamily of GTPbinding proteins. The isoforms are encoded by 
three different genes whereas Kras4A and Kras4B are produced due to differential splicing of the exons. The isoforms differ in short C-terminal regions. For example, Kras4B contains the polylysine sequence and a single farnesyl modification [20]. The isoforms differ at least by four $\mathrm{C}$-terminal amino acid residues. This region is found to be responsible for the variation in the lipid post-translation modifications and membrane localization of the ras isoforms. Though the $\mathrm{H}-, \mathrm{N}-$ and $\mathrm{K}$-ras soforms show similar effector-binding properties they have different biological functions in the development, cell growth and oncogenesis. Quantification of spatiotemporal patterns of Ras isoforms expression during development showed a relative contribution of KRas $4 \mathrm{~B}>>$ NRas $\geq$ KRas $4 A>$ HRas to the total Ras expression with KRas4B typically representing 60$99 \%$ of all Ras transcripts. KRas4A was the most dynamically regulated Ras isoform with significant up-regulation of the expression observed in stomach, intestine, kidney and heart [21]. The functional divergence may be explained, at least partially, by different membrane compartmentalization of the Ras isoforms [22]. Differential distribution of the Ras proteins on cell membranes may be responsible for the unique spatio-temporal models of activation of the effector pathways including the potential and duration of the signal activation [23].

The isoforms of STAT5 protein represent another example of different participation of the protein isoforms in signaling. The STAT (Signal transducers and activators of transcription) proteins are latent cytoplasmic transcription factors coupling the intracellular signals with the target genes expression [24]. STAT5 is directly activated by JAK2 kinase downstream from several cytokine receptors and oncogenic tyrosine kinase BCR-ABL. STAT5 is represented by two proteins: STAT5A and STAT5B, which share $94 \%$ structural homology, but are transcribed from separate genes [25] STAT5A was found preferentially in the mammary tissue while the STAT5B expression was observed mostly in muscle and liver [26]. In the majority of functional tests STAT5A and STAT5B behave similarly [25]. However, downregulation of STAT5B by RNAi essentially inhibited the BCR-ABLdependent hematopoietic cells proliferation [27]. The STAT5B isoform rather than STAT5A is important for the expression of BCL-XL in the presence of BCR-ABL. Moreover, downregulation of STAT5B rather than STAT5A made the BCR-ABL-positive human cells sensitive to the anticancer drug imanitib. Moreover, the expression of STAT5A and STAT5B showed opposite correlations with drug response gene expression [28].

One more example of a differential role of the isoforms in signaling is Rho-associated kinases ROCK1 and ROCK2, which are activated by RhoGTPase and control the cytoskeletal rearrangements. It was shown that despite more than $90 \%$ homology of kinase domains it is the ROCK2 isoform which plays an exclusive role in controlling plasticity of T-cells and macrophage polarization [29].

The adenine nucleotide translocase hANT which exchanges ADP for ATP in the mitochondrial inner membrane and participates in oxidative phosphorylation, is represented by three homologous genes, the expression of which is tissue-specific and depends on physiologic state of a cell. hANT1 is mainly ex- 
pressed in terminally differentiated muscle cells; hANT2 is growth-regulated and is upregulated in highly glycolytic and proliferative cells; and hANT3 is considered to be ubiquitous and non-specifically regulated [30]. The protein partners of the isoforms were found to be similar, and the absence of the main isoform hANT3 had no impact on the oxidative phosphorylation process [31]. However, the isoforms were found to be de-regulated in human tumors [2]. Recently, it has been shown that cancer cells require both hANT2 and hANT3, depending on their proliferation status: hANT2 when proliferation rates are high, and hANT3 when proliferation slows [30].

Thus, the homologous isoforms of the same protein can play different roles in human cells. Possible molecular background for such difference will be discussed below taking as an example the isoforms of translation elongation factor $1 \mathrm{~A}(\mathrm{eEF} 1 \mathrm{~A})$.

\section{The eEF1A1 and eEF1A2 isoforms of translation elongation factor eEF1A}

eEF1A is a translation elongation factor providing the GTP-dependent delivery of aminoacyl-tRNA to the A site of the ribosome. Genome of mammalian cells comprises several eEF1A sequences; however, the only eEF1A1 and eEF1A2 are actively transcribed. Remaining genes are considered retropseudogenes originated from eEF1A1 [32-34]. The EEF1A1 and EEF1A2 genes are localized on 6q14 and 20q13.3 human chromosomes, correspondingly [34]. The coding regions of the corresponding mRNAs are similar by $75 \%$, while the 3' and 5' untranslated regions are completely different [35-37] which opens a way for differential control of the isoforms expression at the post-transcriptional level. The proteins eEF1A1 and eEF1A2 show $97 \%$ homology and $92 \%$ identity. Expression of the isoforms is tissue-specific and mutuallyexclusive. eEF1A1 is a major isoform present everywhere in the organism except neurons, muscles, including cardiac muscles [38, 39] and some specialized cells [40]. The importance of tissue-specific expression of eEF1A2 is highlighted by "wasted" mutation in mouse. Normally, during postnatal development of a mouse the eEF1A1 isoform gradually disappears from muscle and neurons being substituted with eEF1A2. "Wasted" mutation is a deletion of the $e E F 1 A 2$ locus which makes impossible the expression of eEF1A2. As a result, one can observe in the "wasted" mice newborns the major neurological and immunological impairments, starting with $21^{\text {st }}$ day after birth, with their subsequent death on $28^{\text {th }}$ day. These changes parallel the decrease in the eEF1A1 expression which cannot be compensated by the appearance of eEF1A2 in wasted mouse [40, 41].

eEF1A1 is considered a pro-apoptotic protein whereas eEF1A2 shows anti-apoptotic properties [42, 43]. Importantly, eEF1A2 was shown to appear in a number of human cancers of different localization [44-46]. In some cases, this isoform demonstrates the strong oncogenic potential $[45,47]$. The nature of oncogeneity of eEF1A2 is not yet elucidated in detail. It is apparently not related to the gene amplification, mutations in the gene coding region and changes in the gene methylation [48] which suggest that the main contribution should be from a protein molecule per se. There are reports on the participation of eEF1A2 in JAK/STAT and AKT signaling in 
mouse plasmacitomas [49], PI3K/AKT/ mTOR-dependent stabilization of MDM4 [50] and $\mathrm{PI} 3 \mathrm{~K} / \mathrm{Akt} / \mathrm{NF}-\mathrm{kB}$ signaling in hepatocellular carcinomas [51].

\section{Functions of the eEF1A isoforms}

Generally speaking, the translational functions of eEF1A1 and eEF1A2 which show tissuespecific and mutually exclusive localization in an organism should not differ much. This notion is supported by in vitro translation studies [52]. However, it does not preclude a variance in the isoforms interaction with other translation components. For instance, affinity of eEF1A2 for tRNA is somewhat higher than eEF1A1 [53]. GDP dissociation rate constant for eEF1A1 is several fold higher than for eEF1A2 [52]. eEF1A1 shows less affinity for $\mathrm{EF} 1 \mathrm{~B} \alpha$, as compared to eEF1A2 [54] which permitted to suggest that eEF1A2 could be more dependent on the nucleotide exchange factors than eEF1A1. Peculiar in this regard is an observation that the ribosomal elongation rate (reverse to ribosomal transit time) is less in neurons where the only eEF1A2 is expressed than that in glial cells where eEF1A1 is an exclusive isoform $[55,56]$.

Thus, the main translational function of the two isoforms is similar; however, some details of the two isoforms performance during the elongation step may differ. One may speculate that this provides, for example, slower and, supposedly, more precise synthesis of proteins in neurons.

It has become evident that eEF1A plays in cells many non-translational functions as well. It is reported to be involved in the spermatogenesis [57], cell cycle progression [58], chaperon-mediated autophagy [59], protein rena- turation [60], apoptosis [61], lypotoxic cell death [62], endogenous proteolysis [63], cytoskeleton rearrangements [64]. It appears that eEF1A may serve as the important hub protein which links together different cellular processes. An important and still unresolved problem is what could be the mechanism of the distribution of eEF1A between all these processes. We suggest that the eEF1A1 and eEF1A2 isoforms may participate in different processes in cell. The physical basis for this is their different spatial organization, an ability to form dimers, different lipophilic properties [65-67], different number and level of posttranslational modifications [68-70]. The X-ray structure is only known for eEF1A2 [71]. The different features of the isoforms can be considered as providing a specific landscape for different protein-protein interactions of eEF1A1 and eEF1A2, which, in turn, should be a main contributing factor to their dissimilar distribution between cellular processes.

Indeed, some evidence of differential abilities of the isoforms to bind some protein partners has been obtained. eEF1A2 was reported to bind peroxyredoxin 1 helping to protect against oxidative stress [72], and to interact with oncosupressor $\mathrm{p} 16^{\mathrm{INK} 4 \mathrm{a}}$ [73]. eEF1A1 formed complexes with the multifunctiunal Sgt1 protein in vitro and in cellulo while eEF1A2 did not [74]. eEF1A1 rather than eEF1A2 interacted with calmodulin in $\mathrm{Ca}^{2+}$ dependent way [75]. eEF1A is known to interact with actin [76] probably due to its dimeric form [77]. Interestingly, the eEF1A1 and eEF1A2 isoforms induced the formation of differently shaped actin bundles [75] which could be important for a supposed role of eEF1A2 in oncogenesis. 
Summarizing the information on the dissimilarity in eEF1A1 and eEF1A2 interaction with different protein partners one may indicate some important points to consider.

First, as eEF1A2 is found in the excitable tissues (nervous and neuronal) where the processes of the $\mathrm{Ca}^{2+}$-mediated signaling involving a number of $\mathrm{Ca}^{2+}$ binding proteins are very active, it has been suggested that eEF1A2 is less sensitive comparing to eEF1A1 to $\mathrm{Ca}^{2+}$ mediated signaling [75]. This makes translation process more prone to the changes in the concentration of $\mathrm{Ca}^{2+}$ in these tissues. It has been proposed that one of the reasons of the appearance of the eEF1A2 isoform in evolution and the tissue-specific expression of this isoform is a need to protect mRNA translation in the specialized tissues from the influence of regular changes in the $\mathrm{Ca}^{2+}$ concentration observed in these tissues, thus providing a steady level of protein synthesis.

Second, though an oncogenic role of eEF1A2 is still far from being elucidated, one may suggest that eEF1A2 avoids an eEF1A1adapted control in cancer tissues, thus acting in non-controlled or mis-controlled way. It has been proposed that actin-bundling role of A2 should be specially considered as cancer-related one [75] especially taking into account that the dysregulated actin bundling may play a key role in the metastatic processes [78, 79].

Finally, the evolutionary appearance of the isoforms of different proteins evidences for the existence of an additional level of the control of cellular processes. The mechanisms of isoform-specific regulation are not yet known in detail and their understanding still remains mostly at phenomenological level. Thorough examination of the functions and specific pro- tein partners of the isoforms is needed to uncover the molecular instruments of the cell control which depend on the isoforms variance of cellular proteins.

\section{REFERENCES}

1. Gunning $P W$. Protein Isoforms and Isozymes. Encyclopedia of Life Sciences 2006 John Wiley \& Sons.

2. Tress ML, Abascal F, Valencia A. Alternative Splicing May Not Be the Key to Proteome Complexity. Trends Biochem Sci. 2017; 42(2): 98-110.

3. Hedman AC, Smith JM, Sacks DB. The biology of IQGAP proteins: beyond the cytoskeleton. $E M B O$ Rep. 2015; 16(4): 427-46.

4. Wang S, Watanabe T, Noritake J, Fukata M, Yoshimura T, Itoh N, Harada T, Nakagawa M, Matsuura Y, Arimura N, Kaibuchi K. IQGAP3, a novel effector of Rac1 and $\mathrm{Cdc} 42$, regulates neurite outgrowth. J Cell Sci. 2007; 120(Pt 4): 567-77.

5. Ho YD, Joyal JL, Li Z, Sacks DB. IQGAP1 integrates $\mathrm{Ca} 2+/$ calmodulin and $\mathrm{Cdc} 42$ signaling. $J$ Biol Chem. 1999; 274(1): 464-70.

6. Mateer SC, McDaniel AE, Nicolas V, Habermacher GM, Lin M-JS, Cromer DA, King ME, Bloom GS. The mechanism for regulation of the F-actin binding activity of IQGAP1 by calcium/ calmodulin. J Biol Chem. 2002; 277(14): 12324-33.

7. Schmidt VA, Scudder L, Devoe CE, Bernards A, Cupit LD, Bahou WF. IQGAP2 functions as a GTPdependent effector protein in thrombin-induced platelet cytoskeletal reorganization. Blood. 2003; 101(8): 3021-8.

8. Atcheson E, Hamilton E, Pathmanathan S, Greer B, Harriott P, Timson DJ. IQ-motif selectivity in human IQGAP2 and IQGAP3: binding of calmodulin and myosin essential light chain. Biosci Rep. 2011; 31(5): 371-9.

9. Brill S, Li S, Lyman CW, Church DM, Wasmuth JJ, Weissbach L, Bernards A, Snijders AJ. The Ras GTPase-activating-protein-related human protein IQGAP2 harbors a potential actin binding domain and interacts with calmodulin and Rho family GTPases. Mol Cell Biol. 1996; 16(9): 4869-78. 
10. Yang $Y$, Zhao $W$, Xu $Q-W$, Wang $X-S$, Zhang $Y$, Zhang J. IQGAP3 promotes EGFR-ERK signaling and the growth and metastasis of lung cancer cells. PLoS One. 2014; 9(5): e97578.

11. Roy $M$, Li Z, Sacks DB. IQGAP1 is a scaffold for mitogen-activated protein kinase signaling. Mol Cell Biol. 2005; 25(18): 7940-52.

12. Roy M, Li Z, Sacks DB. IQGAP1 binds ERK2 and modulates its activity. J Biol Chem. 2004; 279(17): 17329-37.

13. Adachi M, Kawasaki A, Nojima H, Nishida E, Tsukita $S$. Involvement of IQGAP family proteins in the regulation of mammalian cell cytokinesis. Genes Cells. 2014; 19(11): 803-20.

14. Smith EA, Fuchs E. Defining the interactions between intermediate filaments and desmosomes. $J$ Cell Biol. 1998; 141(5): 1229-41.

15. Bass-Zubek AE, Godsel LM, Delmar M, Green KJ. Plakophilins: multifunctional scaffolds for adhesion and signaling. Curr Opin Cell Biol. 2009; 21(5): 708-16.

16. Asimaki A, Protonotarios A, James CA, Chelko SP, Tichnell C, Murray B, Tsatsopoulou A, Anastasakis $A$, te Riele A, Kleber AG, Judge DP, Calkins H, Saffitz JE. Characterizing the Molecular Pathology of Arrhythmogenic Cardiomyopathy in Patient Buccal Mucosa Cells. Circ Arrhythm Electrophysiol. 2016; 9(2): e003688.

17. Dubash AD, Kam CY, Aguado BA, Patel DM, Delmar $M$, Shea LD, Green KJ. Plakophilin-2 loss promotes TGF-beta1/p38 MAPK-dependent fibrotic gene expression in cardiomyocytes. $J$ Cell Biol. 2016; 212(4): 425-38.

18. Miyazaki K, Yoshizaki K, Arai C, Yamada A, Saito K, Ishikawa M, Xue H, Funada K, Haruyama N, Yamada Y, Fukumoto S, Takahashi I. Plakophilin-1, a Novel Wnt Signaling Regulator, Is Critical for Tooth Development and Ameloblast Differentiation. PLoS One. 2016; 11(3): e0152206.

19. Keil R, Rietscher K, Hatzfeld M. Antagonistic regulation of intercellular cohesion by plakophilins 1 and 3. J Invest Dermatol. 2016;136(10):2022-9.

20. Jang H, Abraham SJ, Chavan TS, Hitchinson B, Khavrutskii L, Tarasova NI, Nussinov R, Gaponenko $V$. Mechanisms of membrane binding of small
GTPase K-Ras4B farnesylated hypervariable region. $J$ Biol Chem. 2015; 290(15): 9465-77.

21. Newlaczyl AU, Coulson JM, Prior IA. Quantification of spatiotemporal patterns of Ras isoform expression during development. Sci Rep. 2017; 741297.

22. Gregory MC, McLean MA, Sligar SG. Interaction of KRas4b with anionic membranes: A special role for PIP2. Biochem Biophys Res Commun. 2017; 487(2): 351-5.

23. Quinlan MP, Settleman J. Isoform-specific ras functions in development and cancer. Future Oncol. 2009; 5(1): 105-16.

24. Furigo IC, Ramos-Lobo AM, Frazao R, Donato JJ. Brain STAT5 signaling and behavioral control. Mol Cell Endocrinol. 2016;438:70-76.

25. Able AA, Burrell JA, Stephens JM. STAT5-Interacting Proteins: A Synopsis of Proteins that Regulate STAT5 Activity. Biology (Basel). 2017; 6(1):pii: E20.

26. Hennighausen L, Robinson GW. Interpretation of cytokine signaling through the transcription factors STAT5A and STAT5B. Genes Dev. 2008; 22(6): 711-21.

27. Schaller-Schonitz M, Barzan D, Williamson AJK, Griffiths JR, Dallmann I, Battmer K, Ganser A, Whetton AD, Scherr M, Eder M. BCR-ABL affects STAT5A and STAT5B differentially. PLoS One. 2014; 9(5): e97243.

28. Lamba V, Jia B, Liang F. STAT5A and STAT5B have opposite correlations with drug response gene expression. Biochem Biophys Res Commun. 2016;

29. Zanin-Zhorov A, Flynn R, Waksaland SD, Blazar $B R$. Isoform-specific targeting of ROCK proteins in immune cells. Small GTPases. 2016; 1-5.

30. Gavalda-Navarro A, Mampel T, Vinas O. Changes in the expression of the human adenine nucleotide translocase isoforms condition cellular metabolic/ proliferative status. Open Biol. 2016; 6(2): 150108.

31. Lu Y-W, Acoba MG, Selvaraju K, Huang T-C, Nirujogi RS, Sathe G, Pandey A, Claypool SM. Human adenine nucleotide translocases physically and functionally interact with respirasomes. Mol Biol Cell. 2017; 28(11): 1489-506.

32. Madsen HO, Poulsen K, Dahl O, Clark BF, Hjorth JP. Retropseudogenes constitute the major 
part of the human elongation factor 1 alpha gene family. Nucleic Acids Res. 1990; 18(6): 1513-6.

33. Lee S, Wolfraim LA, Wang E. Differential expression of S1 and elongation factor-1 alpha during rat development. J Biol Chem. 1993; 268(32): 24453-9.

34. Lund A, Knudsen SM, Vissing H, Clark B, Tommerup $N$. Assignment of human elongation factor 1alpha genes: EEF1A maps to chromosome 6q14 and EEF1A2 to 20q133. Genomics. 1996; 36(2): 35961.

35. Knudsen SM, Frydenberg J, Clark BF, Leffers $H$. Tissue-dependent variation in the expression of elongation factor-1 alpha isoforms: isolation and characterisation of a cDNA encoding a novel variant of human elongation-factor 1 alpha. Eur J Biochem. 1993; 215(3): 549-54.

36. Bischoff C, Kahns S, Lund A, Jorgensen HF, Praestegaard $M$, Clark BF, Leffers $H$. The human elongation factor $1 \mathrm{~A}-2$ gene (EEF1A2): complete sequence and characterization of gene structure and promoter activity. Genomics. 2000; 68(1): 63-70.

37. Vislovukh AA, Naumovets $M G$, Kovalenko MI, Groisman RS, Groisman IS, Negrutskii BS, El'skaya $A V$. Isoforms of elongation factor eEF1A may be differently regulated at post-transcriptional level in breast cancer progression. Biopolym Cell. 2013; 29(1): 55-63.

38. Ann DK, Lin HH, Lee S, Tu ZJ, Wang E. Characterization of the statin-like $\mathrm{S} 1$ and rat elongation factor 1 alpha as two distinctly expressed messages in rat. $J$ Biol Chem. 1992; 267(2): 699-702.

39. Lee S, Francoeur AM, Liu S, Wang E. Tissue-specific expression in mammalian brain, heart, and muscle of S1, a member of the elongation factor-1 alpha gene family. J Biol Chem. 1992; 267(33): 24064-8.

40. Newbery HJ, Loh DH, O'Donoghue JE, Tomlinson VAL, Chau Y-Y, Boyd JA, Bergmann JH, Brownstein D, Abbott CM. Translation elongation factor eEF1A2 is essential for post-weaning survival in mice. J Biol Chem. 2007; 282(39): 28951-9.

41. Doig J, Griffiths LA, Peberdy D, Dharmasaroja P, Vera M, Davies FJC, Newbery HJ, Brownstein D, Abbott CM. In vivo characterization of the role of tissue-specific translation elongation factor $1 \mathrm{~A} 2$ in protein synthesis reveals insights into muscle atrophy. FEBS J. 2013; 280(24): 6528-40.

42. Ruest L-B, Marcotte R, Wang E. Peptide elongation factor eEF1A-2/S1 expression in cultured differentiated myotubes and its protective effect against caspase-3-mediated apoptosis. J Biol Chem. 2002; 277(7): 5418-25.

43. Abbott CM, Newbery HJ, Squires CE, Brownstein D, Griffiths LA, Soares DC. eEF1A2 and neuronal degeneration. Biochem Soc Trans. 2009; 37(Pt 6): 1293-7.

44. Anand N, Murthy S, Amann G, Wernick M, Porter LA, Cukier IH, Collins C, Gray JW, Diebold J, Demetrick DJ, Lee JM. Protein elongation factor EEF1A2 is a putative oncogene in ovarian cancer. Nat Genet. 2002; 31(3): 301-5.

45. Pinke DE, Kalloger SE, Francetic T, Huntsman DG, Lee $J M$. The prognostic significance of elongation factor eEF1A2 in ovarian cancer. Gynecol Oncol. 2008; 108(3): 561-8.

46. Joseph P, O'Kernick CM, Othumpangat S, Lei Y-X, Yuan B-Z, Ong T-M. Expression profile of eukaryotic translation factors in human cancer tissues and cell lines. Mol Carcinog. 2004; 40(3): 171-9.

47. Tomlinson VAL, Newbery HJ, Wray NR, Jackson J, Larionov A, Miller WR, Dixon JM, Abbott CM. Translation elongation factor eEF1A2 is a potential oncoprotein that is overexpressed in two-thirds of breast tumours. BMC Cancer. 2005; 5113.

48. Tomlinson VAL, Newbery HJ, Bergmann JH, Boyd J, Scott D, Wray NR, Sellar GC, Gabra H, Graham A, Williams ARW, Abbott CM. Expression of eEF1A2 is associated with clear cell histology in ovarian carcinomas: overexpression of the gene is not dependent on modifications at the EEF1A2 locus. $\mathrm{Br}$ J Cancer. 2007; 96(10): 1613-20.

49. Li Z, Qi C-F, Shin D-M, Zingone A, Newbery HJ, Kovalchuk AL, Abbott CM, Morse HC 3rd. Eefla2 promotes cell growth, inhibits apoptosis and activates JAK/STAT and AKT signaling in mouse plasmacytomas. PLoS One. 2010; 5(5): e10755.

50. Pellegrino R, Calvisi DF, Neumann O, Kolluru V, Wesely J, Chen X, Wang C, Wuestefeld T, Ladu S, Elgohary N, Bermejo JL, Radlwimmer B, Zornig M, Zender L, Dombrowski F, Evert M, Schirmacher P, 
Longerich T. EEF1A2 inactivates p53 by way of PI3K/AKT/mTOR-dependent stabilization of MDM4 in hepatocellular carcinoma. Hepatology. 2014; 59(5): 1886-99.

51. Qiu F-N, Huang $Y$, Chen D-Y, Li F, Wu Y-A, Wu W-B, Huang $X-L$. Eukaryotic elongation factor-1alpha 2 knockdown inhibits hepatocarcinogenesis by suppressing PI3K/Akt/NF-kappaB signaling. World $J$ Gastroenterol. 2016; 22(16): 4226-37.

52. Kahns S, Lund A, Kristensen P, Knudsen CR, Clark BF, Cavallius J, Merrick WC. The elongation factor 1 A-2 isoform from rabbit: cloning of the cDNA and characterization of the protein. Nucleic Acids Res. 1998; 26(8): 1884-90.

53. Futernyk $P$ V., Negrutskii BS, El'skaya A V. Interaction of different $t R N A$ s with translation elongation factors 1 A from lower and higher eukaryotes. Biopolym Cell. 2009; 25(6): 457-65.

54. Trosiuk T V, Shalak VF, Szczepanowski RH, Negrutskii $B S$, El'skaya $A V$. A non-catalytic $\mathrm{N}$-terminal domain negatively influences the nucleotide exchange activity of translation elongation factor 1Balpha. FEBS J. 2015; 283(3): 484-97.

55. Takei N, Kawamura M, Ishizuka Y, Kakiya N, Inamura N, Namba H, Nawa H. Brain-derived neurotrophic factor enhances the basal rate of protein synthesis by increasing active eukaryotic elongation factor 2 levels and promoting translation elongation in cortical neurons. $J$ Biol Chem. 2009; 284(39): 26340-8.

56. Barrera I, Flores-Mendez M, Hernandez-Kelly LC, Cid L, Huerta M, Zinker S, Lopez-Bayghen E, Aguilera J, Ortega A. Glutamate regulates eEF1A phosphorylation and ribosomal transit time in Bergmann glial cells. Neurochem Int. 2010; 57(7): 795-803.

57. Tash JS, Attardi B, Hild SA, Chakrasali R, Jakkaraj SR, Georg GI. A novel potent indazole carboxylic acid derivative blocks spermatogenesis and is contraceptive in rats after a single oral dose. Biol Reprod. 2008; 78(6): 1127-38.

58. Mishra AK, Gangwani L, Davis RJ, Lambright DG. Structural insights into the interaction of the evolutionarily conserved ZPR1 domain tandem with eukaryotic EF1A, receptors, and SMN complexes. Proc Natl Acad Sci U S A. 2007; 104(35): 13930-5.
59. Bandyopadhyay U, Sridhar S, Kaushik S, Kiffin R, Cuervo AM. Identification of regulators of chaperone-mediated autophagy. Mol Cell. 2010; 39(4): 535-47.

60. Lukash TO, Turkivska H V, Negrutskii BS, El'skaya $A V$. Chaperone-like activity of mammalian elongation factor eEF1A: renaturation of aminoacyl-tRNA synthetases. Int J Biochem Cell Bio.l 2004; 36(7): 1341-7.

61. Lamberti A, Caraglia M, Longo O, Marra M, Abbruzzese A, Arcari P. The translation elongation factor $1 \mathrm{~A}$ in tumorigenesis, signal transduction and apoptosis: review article. Amino Acids. 2004; 26(4): 443-8.

62. Borradaile NM, Buhman KK, Listenberger LL, Magee CJ, Morimoto ETA, Ory DS, Schaffer JE. A critical role for eukaryotic elongation factor $1 \mathrm{~A}-1$ in lipotoxic cell death. Mol Biol Cell. 2006; 17(2): $770-8$.

63. Chen L, Madura K. Increased proteasome activity, ubiquitin-conjugating enzymes, and eEF1A translation factor detected in breast cancer tissue. Cancer Res. 2005; 65(13): 5599-606.

64. Jeganathan S, Morrow A, Amiri A, Lee JM. Eukaryotic elongation factor $1 \mathrm{~A} 2$ cooperates with phosphatidylinositol-4 kinase III beta to stimulate production of filopodia through increased phosphatidylinositol-4,5 bisphosphate generation. Mol Cell Biol. 2008; 28(14): 4549-61.

65. Shalak VF, Vislovukh AA, Novosylna O V, Khoruzhenko AI, Kovalenko MI, Kolesanova EF, Egorova EA, Mishin AA, Krotevych MS, Skoroda L V. Characterization of novel peptide-specific antibodies against the translation elongation factor eEF1A2 and their application for cancer research. Biopolym Cell. 2014; 30(6): 454-61.

66. Timchenko AA, Novosylna $O V$, Prituzhalov EA, Kihara H, El'skaya A V, Negrutskii BS, Serdyuk IN. Different oligomeric properties and stability of highly homologous A1 and proto-oncogenic A2 variants of mammalian translation elongation factor eEF1. Biochemistry. 2013; 52(32): 5345-53.

67. Budkevich TV, Timchenko AA, Tiktopulo EI, Negrutskii BS, Shalak VF, Petrushenko ZM, Aksenov VL, Willumeit R, Kohlbrecher J, Serdyuk IN, 
El'skaya $A \mathrm{~V}$. Extended conformation of mammalian translation elongation factor $1 \mathrm{~A}$ in solution. Biochemistry. 2002; 41(51): 15342-9.

68. Negrutskii B, Vlasenko D, El'skaya A. From global phosphoproteomics to individual proteins: the case of translation elongation factor eEF1A. Expert Rev Proteomics. 2012; 9(1): 71-83.

69. Soares DC, Abbott CM. Highly homologous eEF1A1 and eEF1A2 exhibit differential post-translational modification with significant enrichment around localised sites of sequence variation. Biol Direct. 2013; 8:29.

70. Kanibolotsky DS, Novosyl'na $O$ V, Abbott CM, Negrutskii BS, El'skaya A V. Multiple molecular dynamics simulation of the isoforms of human translation elongation factor 1A reveals reversible fluctuations between "open" and "closed" conformations and suggests specific for eEF1A1 affinity for Ca2+-calmodulin. BMC Struct Biol. 2008; 8:4.

71. Crepin T, Shalak VF, Yaremchuk AD, Vlasenko DO, McCarthy A, Negrutskii BS, Tukalo MA, El'skaya AV. Mammalian translation elongation factor eEF1A2: X-ray structure and new features of GDP/GTP exchange mechanism in higher eukaryotes. Nucleic Acids Res. 2014; 42(20): 12939-48.

72. Chang $R$, Wang $E$. Mouse translation elongation factor eEF1A-2 interacts with Prdx-I to protect cells against apoptotic death induced by oxidative stress. $J$ Cell Biochem. 2007; 100(2): 267-78.

73. Lee M-H, Choi BY, Cho Y-Y, Lee S-Y, Huang Z, Kundu JK, Kim MO, Kim DJ, Bode AM, Surh Y-J, Dong Z. Tumor suppressor p16(INK4a) inhibits cancer cell growth by downregulating eEF1A2 through a direct interaction. $J$ Cell Sci. 2013; 126(Pt 8): 1744-52.

74. Novosylna O, Jurewicz E, Pydiura N, Goral A, Filipek A, Negrutskii B, El'skaya A. Translation elongation factor eEF1A1 is a novel partner of a multifunctional protein Sgt1. Biochimie. 2015; 119137-45.

75. Novosylna O, Doyle A, Vlasenko D, Murphy $M$, Negrutskii B, El'skaya A. Comparison of the ability of mammalian eEF1A1 and its oncogenic variant eEF1A2 to interact with actin and calmodulin. Biol Chem. 2017; 398(1): 113-24.
76. Erasmus JC, Bruche S, Pizarro L, Maimari N, Pogglioli T, Tomlinson C, Lees J, Zalivina I, Wheeler A, Alberts A, Russo A, Braga VMM. Defining functional interactions during biogenesis of epithelial junctions. Nat Commun. 2016; $7: 13542$.

77. Vlasenko DO, Novosylna $O V$, Negrutskii $B S$, El'skaya $A V$. Truncation of the A, A*, $\mathrm{A}^{\prime}$ helices segment impairs the actin bundling activity of mammalian eEF1A1. FEBS Lett. 2015; 589(11): 118793.

78. Hashimoto Y, Parsons M, Adams JC. Dual actinbundling and protein kinase C-binding activities of fascin regulate carcinoma cell migration downstream of Rac and contribute to metastasis. Mol Biol Cell. 2007; 18(11): 4591-602.

79. Stevenson RP, Veltman D, Machesky LM. Actinbundling proteins in cancer progression at a glance. J Cell Sci. 2012; 125(Pt 5): 1073-9.

\section{Ізоформи білків. Походження, структура та функції}

О. В. Новосильна

Велика кількість білків в організмі ссавців існує у вигляді декількох ізоформ. Ці варіанти кодуються різними генами або є сплайсованими модифікаціями продуктів того ж самого гена. Незважаючи на швидкий інструментальний прогрес у ідентифікації ізоформ, причини їх існування та специфічні функції у більшості випадків залишаються достеменно невідомими. Останнім часом увага дослідників здебільшого зосереджена на сплайсованих ізоформах, у той час як різногенні білкові ізоформи можуть відігравати суттєву роль у різних клітинних процесах. У огляді наводяться приклади різних потенційних функцій ізоформ того ж самого білка, які кодуються різними генами. Молекулярне підгрунтя, що може забезпечувати існування такої різниці функцій у високогомологічних білкових ізоформ обговорюється на прикладі останніх досягнень у вивченні ізоформ фактора елонгації трансляції 1А (eEF1A).

Кл юч о в і с л о в а: білкові ізоформи, еукаріотична трансляція, еEF1A 


\section{Изоформы белков: Происхождение структура и функции}

\section{А. В. Новосильная}

Многие белки в организме млекопитающих существует в виде нескольких изоформ. Эти изоформы кодируются разными генами или являются продуктами альтернативного сплайсинга одного и того же гена. Несмотря на быстрый инструментальный прогресс в идентификации изоформ, причины их существования и специфические функции в большинстве случаев остаются точно неизвестными. В последнее время внимание исследователей в основном сосредоточено на сплайсированных изоформах, в то время как разно- генные белкоые изоформы могут исполнять существенную роль в разных клеточных процессах. В обзоре приводятся примеры разных потенциальных функций изоформ одного и того же белка, кодируемых разными генами. Молекулярные основы существования такой функциональной разницы высокогомологичных белковых изоформ обсуждаются на примере последних достижений в изучении изоформ фактора элонгации трансляции 1А (eEF1A).

К л юч е в ы е с л ов а: белквые изоформы, эукариотическая трансляция, eEF1A 